\title{
GENERALIZED CONSTITUTIVE MODEL FOR STABILIZED QUICK CLAY
}

PANCRAS MUGISHAGWE BUJULU AND GUSTAV GRIMSTAD

\begin{abstract}
An experimentally-based two yield surface constitutive model for cemented quick clay has been developed at NTNU, Norway, to reproduce the mechanical behavior of the stabilized quick clay in the triaxial pêq stress space. The model takes into account the actual mechanical properties of the stabilized material, such as rattractionò friction angle and destructuration. A further attempt has been made to extend the formulation into the full stress space, based on the Hardening Soil Model, the SClay Model, the Koiter Rule and two Mapping Rules. A generalized 3D-constitutive model for stabilized quick clay has been formulated. This paper discusses the formulation process and presents the resulting generalized model.
\end{abstract}

KEYWORDS: Constitutive model, Quick clay, Destructuration, Hardening rule, Yield surface

\section{INTRODUCTION}

Engineering properties of stabilized materials depend on the fabric and particle cementation resulting from the chemical reaction of the binders. Such soils display a substantial amount of intrinsic stiffness and strength when subjected to an external loading. However, when the applied stress exceeds the bond strength, the bonds break and eventually the microstructure collapses; the phenomenon known as r̃destructurationò Prediction of the mechanical behaviour of such materials has been formulated in form of a constitutive model (QUICKSTAB) as proposed by Bujulu and Grimstad (2012). However, the formulation was limited to the twodimensional triaxial (pôq) stress space.

In order to get a generalized model, an attempt has been made to extend the model formulation into the full (3-dimensional) stress space. This paper discusses formulation of the generalized model based on the Hardening Soil Model (Brinkgreve et al. 2006), the S-Clay1 model (Wheeler et. al. 2003), and formulations by Søreide (2002) and Dafalias and Manzari (2004). As a background for this extension, the pô $q$ formulation (Bujulu and Grimstad, 2012) is first summarized below, with the extension presented thereafter in the succeeding section.

\section{CONSTITUTIVE EQUATIONS IN TRIAXIAL STRESS SPACE}

In the pô q stress space the model takes the form of two yield surfaces, appearing as a r̃capòand a ñwedgeòin the two axes, respectively. The cap is mainly meant to model the volumetric (oedometric) behaviour and the wedge is meant to model the deviatoric behaviour.

Pancras Mugishagwe Bujulu, College of Engineering and Technology, University of Dar es Salaam, Tanzania

Gustav Grimstad, Norwegian University of Science and Technology, NTNU, Trondheim, Norway 


\section{Cap Yield Surface}

The cap surface is given in Equation (1) as:

$$
F_{c}=q^{2}+\mathrm{M}^{2} \cdot\left(\left(p^{1}+a_{c}\right)^{2}-p_{m}{ }^{2}\right)=0 \quad \text { é é é é é é é é é é é é é é é é é é } .
$$

where $z$ (Greek capital $\varepsilon$ ) is an internal parameter related to the earth pressure coefficient under virgin loading, $\mathrm{K}_{0}{ }^{\mathrm{NC}} ; \mathrm{p}_{\mathrm{m}}$ î is the size of the cap and $a_{c}$ is the attraction for the cap.

It may be shown, due to the strain requirement in oedometric condition and through an associated flow rule, that $\mathrm{M}$ will be given by Equation (2), assuming infinite elastic stiffness. $\mathrm{K}_{0}{ }^{\mathrm{NC}}$ is in this case obtained by including the $\mathrm{a}_{\mathrm{c}}$ term for the stresses. $Z$ is easily obtained by a stress condition in which $\mathrm{a}_{\mathrm{c}}<<$ pô

$$
\mathrm{M} \approx \sqrt{\frac{3}{2} \cdot \frac{3\left(1-K_{0}^{N C}\right)}{1+2 K_{0}^{N C}}}
$$

\section{Hardening Rules for the Cap}

Two hardening rules are used for the cap surface. Firstly, an isotropic hardening rule which includes the possibility for a constant term. The expression takes the form:

$$
\frac{d p_{m}{ }^{\prime}}{d \lambda_{c}}=\left(p_{m} \cdot \frac{1}{\zeta}+\mathrm{Z}_{a}\right) \cdot \frac{\partial F_{c}}{\partial p^{\prime}}
$$

where 6 and $\ell_{a}$ are parameters controlling the hardening of the cap.

The second cap hardening rule is the attraction softening. Under oedometeric condition (isolating the cap behavior) two types of attraction softening may generally be experienced. Type I is given by a destructuration rule (Karstunen et al., 2006), whereas Type II is associated with the loss of the $a_{c}$ term in the yield criterion for the cap. The following softening rule for $\mathrm{a}_{\mathrm{c}}$ (Equation 4) was proposed due to the cap type plasticity (Bujulu and Grimstad, 2012).

$$
\frac{d a_{c}}{d \lambda_{c}}=-a_{c} \cdot \mu_{a c} \cdot \frac{\partial F_{c}}{\partial p^{\prime}} \quad \text { é é é é é é é é é é é é é é é é é é é é é é é }
$$

where $\mu_{a c}$ is a hardening parameter.

\section{Wedge (cone) yield and potential surface}

The cone yield surface appears in the pô q stress space as a wedge, as expressed by Equation(5).

$$
F_{w}=\left|q-\left(p^{\prime}+a_{w}\right) \cdot \alpha\right|-m \cdot\left(p^{\prime}+a_{w}\right)=0
$$

$$
\text { é é é é é é é é é é é é é é é é . }
$$

where $\breve{U}$ is the rotation of the wedge in the pô q space; $m$ is the size of the wedge and $a_{w}$ is the attraction for the wedge. 
The size parameter $\mathrm{m}$ will be a small number and will be given a default value of $0.01 \cdot M_{c, f}$. Where $M_{c, f}$ is the maximum value of $\mathrm{q} /\left(\mathrm{p} \hat{\mathrm{G}} \mathrm{a}_{\mathrm{w}}\right)$ in a triaxial compression test. The potential surface is not directly needed, only its derivatives with respect to the stress components (Equation (6)).

$$
\left[\begin{array}{c}
\frac{\partial Q_{w}}{\partial p^{\prime}} \\
\frac{\partial Q_{w}}{\partial q}
\end{array}\right]=\left[\begin{array}{c}
f_{Q}\left(q, p^{\prime}, a_{w}\right) \\
\frac{\partial F_{w}}{\partial q}
\end{array}\right]
$$

where $f_{Q(q, p o p a w) ~}$ is a dilatancy/contractancy parameter, which in general may be stress dependent. Equation (7) gives a suggestion for a possible mathematical expression for $\mathrm{f}_{\mathrm{Q}}$. In contrast to other models, where a mobilization formulation is used, this is independent of $\mathrm{q}$.

$$
f_{Q}=\frac{a_{w}}{p^{\prime}+a_{w}} \cdot \frac{\partial F_{w}}{\partial p^{\prime}}
$$

The kinematic hardening rule for the wedge is given as:

$\frac{d \alpha}{d \lambda_{w}}=f_{\alpha}\left(q, p^{\prime}, a_{w}, \frac{\partial F_{w}}{\partial q}\right)$

where $f_{\breve{U}}$ may be determined by curve-fitting with the laboratory experiments or by choosing some basic functions. For $f_{\breve{u}}$ we will have the following requirements

$$
\begin{aligned}
& f_{\alpha}=0 \quad \frac{q}{p^{\prime}+a_{w}}=M_{f} \quad\left(\mathrm{M}_{\mathrm{f}}\right. \text { is the failure criteria) } \\
& f_{\alpha} \rightarrow \infty \text { for stress reversal or initial shearing }
\end{aligned}
$$

The function given by Equation (9) may be used in triaxial stress-strain space.

$$
\frac{d \alpha}{d \lambda_{w}}=\mu_{w} \cdot \frac{1}{\left(M_{c, f}+M_{e, f}\right) \cdot \frac{\partial F_{w}}{\partial q}} \cdot\left(\frac{q_{b}-q}{p^{\prime}+a_{w}}\right)^{2}
$$

where $q_{b}$ is the bounding deviatoric stress

In the triaxial shearing tests the material shows rattraction softeningò(cohesion softening), expressed by Equation (10).

$$
\frac{d a_{w}}{d \lambda_{w}}=-a_{w} \cdot \mu_{a w} \cdot\left|\frac{q}{p^{\prime}+a_{w}}\right| \quad \text { é é é é é é é é é é é é é é é é é é é é é é é é é é } . .
$$

where $\varepsilon_{\mathrm{aw}}$ is a hardening parameter. 


\section{THEORY OF MULTIPLE YIELD SURFACE MODELING}

The rule for adding response from several yield criteria and plastic potential functions is known as the Koiter rule (Schanz et. al., 1999). This may be presented as Equation (11):

$d \boldsymbol{\varepsilon}^{p}=\sum_{i}\left(d \lambda_{i} \cdot \frac{\partial Q_{i}}{\partial \boldsymbol{\sigma}}\right) \quad$ é é é é é é é é é é é é é é é é é é é é é é é é é é é

where the plastic multiplier, $d \lambda_{i}$, is given by Equation (12):

$d \lambda_{i}=\frac{1}{A_{i}} \cdot\left\{\frac{\partial F_{i}}{\partial \boldsymbol{\sigma}}\right\}^{T} \cdot d \boldsymbol{\sigma} \quad$ é é é é é é é é é é é é é é é é é é é é é é é é é é é.

where $A_{i}=-\sum_{j} \frac{\partial F}{\partial \kappa_{j}} \cdot \frac{d \kappa_{j}}{d \lambda_{i}}$

Let us assume two yield criteria are violated. We may now write:

$d \boldsymbol{\sigma}=\mathbf{D}_{e} \cdot\left(d \boldsymbol{\varepsilon}-d \lambda_{1} \cdot \frac{\partial Q_{1}}{\partial \boldsymbol{\sigma}}-d \lambda_{2} \cdot \frac{\partial Q_{2}}{\partial \boldsymbol{\sigma}}\right) \quad$ é é é é é é é é é é é é é é é é é é é é..

where $D_{e}$ is the elastic stiffness matrix.

Using the equations above we get expressions for the two plastic multipliers:

$d \lambda_{1}=\frac{\left(A_{2}+a_{22}\right) \cdot\left\{\frac{\partial F_{1}}{\partial \boldsymbol{\sigma}}\right\}^{T}-a_{12} \cdot\left\{\frac{\partial F_{2}}{\partial \boldsymbol{\sigma}}\right\}^{T}}{\left(A_{1}+a_{11}\right) \cdot\left(A_{2}+a_{22}\right)-a_{12} \cdot a_{21}} \cdot \mathbf{D}_{e} \cdot d \boldsymbol{\varepsilon} \quad$ é é é é é é é é é é é é é é é é é.

$d \lambda_{2}=\frac{\left(A_{1}+a_{11}\right) \cdot\left\{\frac{\partial F_{2}}{\partial \boldsymbol{\sigma}}\right\}^{T}-a_{21} \cdot\left\{\frac{\partial F_{1}}{\partial \boldsymbol{\sigma}}\right\}^{T}}{\left(A_{2}+a_{22}\right) \cdot\left(A_{1}+a_{11}\right)-a_{21} \cdot a_{12}} \cdot \mathbf{D}_{e} \cdot d \boldsymbol{\varepsilon} \quad$ é é é é é é é é é é é é é é é é é $\ldots$

where $a_{i j}=\left\{\frac{\partial F_{i}}{\partial \boldsymbol{\sigma}}\right\}^{T} \cdot \mathbf{D}_{e} \cdot \frac{\partial Q_{j}}{\partial \boldsymbol{\sigma}}$

A numerical scheme is used to activate the plastic multiplier for only the violated yield criteria. 


\section{GENERALIZATION TO 3D}

\section{Cap surface}

The cap surface (yield and potential) is isotropic and Lode angle independent, hence a direct transformation to full stress space can simply be done by transformation of the derivatives by parts, as given by Equation (16)

$\frac{\partial F_{c}}{\partial \boldsymbol{\sigma}^{\prime}}=\frac{\partial q}{\partial \boldsymbol{\sigma}^{\prime}} \cdot \frac{\partial F_{c}}{\partial q}+\frac{\partial p^{\prime}}{\partial \boldsymbol{\sigma}^{\prime}} \cdot \frac{\partial F_{c}}{\partial p^{\prime}} \quad$ é é é é é é é é é é é é é é é é é é é é é é é é..

\section{Cone surface}

The cone yield surface and its potential surface have a slightly more cumbersome generalization procedure. In the 'i plane the cone and the failure criteria will be as shown in Figure 1. First we need to decide on a mapping rule and normal to the potential surface, Ö/Öiô The kinematic (rotational) parameter, Ŭ, must be replaced by a rotational tensor $\boldsymbol{\alpha}$. The generalized yield surface is given by Equation (17).

$$
F_{w}=\sqrt{\frac{3}{2}\left(\begin{array}{l}
\left.\left\{\boldsymbol{\sigma}_{d}-\left(p^{\prime}+a\right) \boldsymbol{\alpha}_{d}\right\}^{T}\right) \\
\cdot\left\{\boldsymbol{\sigma}_{d}-\left(p^{\prime}+a\right) \boldsymbol{\alpha}_{d}\right\}
\end{array}\right)}-m\left(p^{\prime}+a\right)=0 \quad \text { é é é é é é é é é é é é é é é é é } . .
$$

where:

$$
\boldsymbol{\sigma}_{d}=\left[\begin{array}{c}
\sigma_{x}{ }^{\prime}-p^{\prime} \\
\sigma_{y}{ }^{\prime}-p^{\prime} \\
\sigma_{z}{ }^{\prime}-p^{\prime} \\
\sqrt{2} \tau_{x y} \\
\sqrt{2} \tau_{x z} \\
\sqrt{2} \tau_{y z}
\end{array}\right], \boldsymbol{\alpha}_{d}=\left[\begin{array}{c}
\alpha_{x}-1 \\
\alpha_{y}-1 \\
\alpha_{z}-1 \\
\sqrt{2} \alpha_{x y} \\
\sqrt{2} \alpha_{x z} \\
\sqrt{2} \alpha_{y z}
\end{array}\right]
$$

The kinematic hardening rule (previously presented as Equation (9)) could now be rewritten as:

$$
\frac{d \boldsymbol{\alpha}_{d}}{d \lambda_{w}}=\mu_{w} \cdot \frac{\left\{\boldsymbol{\sigma}_{b, d}-\boldsymbol{\sigma}_{d}\right\}^{T} \cdot \frac{\partial F_{w}}{\partial \boldsymbol{\sigma}_{d}}}{\left\{\boldsymbol{\sigma}_{b, d}-\boldsymbol{\sigma}_{b, d} *\right\}^{T} \cdot \frac{\partial Q_{w}}{\partial \boldsymbol{\sigma}_{d}}} \cdot \frac{\left(\boldsymbol{\sigma}_{b, d}-\boldsymbol{\sigma}_{d}\right)}{\left(p^{\prime}+a_{w}\right)} \quad \text { é é é é é é é é é é é é é é é é é é }
$$




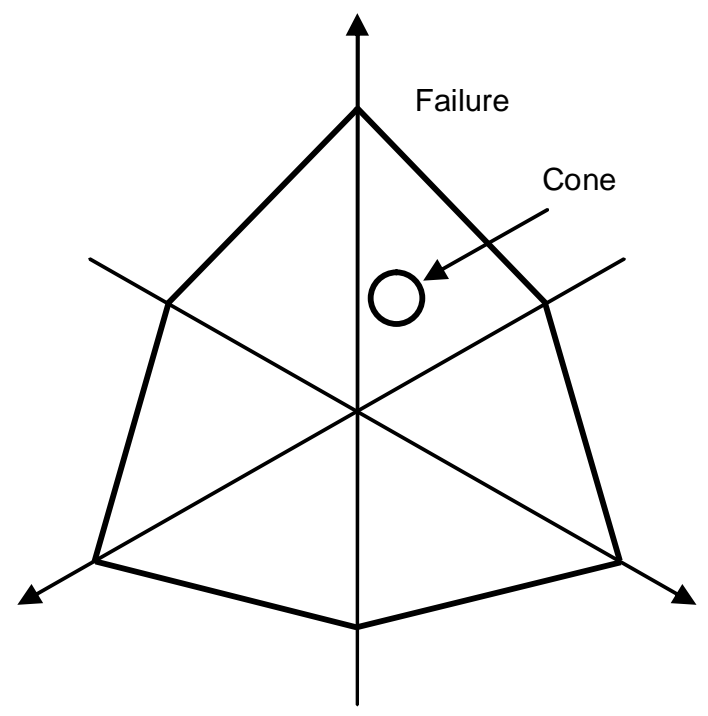

Figure 1: Mohr Coulomb and cone surfaces in the ' ï plane

\section{The mapping rule}

The bounding surface stress is mapped from the current stress condition through a mapping rule. Various mapping rules may be found in the literature (Andrianopoulos et al., 2005). In this study two mapping rules are emphasised. For simplicity a constant $J_{2}$ criteria is chosen for the presentation of the possible mapping rules. If we have a potential surface equivalent to the constant $J_{2}$ criteria we may use Figure 2 directly to set up our equations.

Mapping rule (a) uses the same direction (Modified Lode angle) for the small cone and for the bounding surface (from isotropic state) to find the bounding stress. Mapping rule (b) maps the bounding stress directly through the stress direction on the cone. Several other mapping possibilities exist, involving, for instance, stress reversal points or mobilisation surfaces. (a)

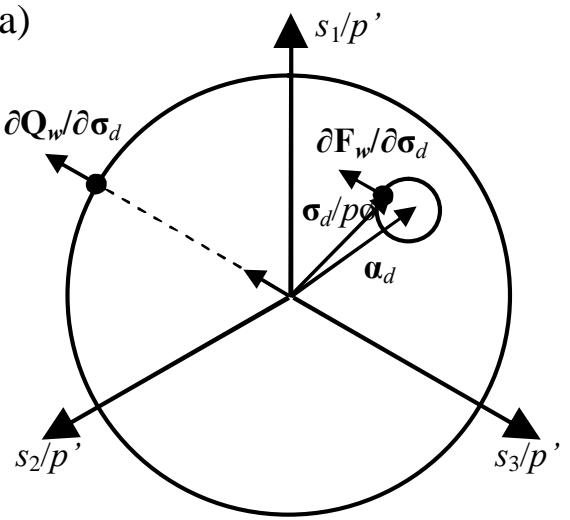

(b)

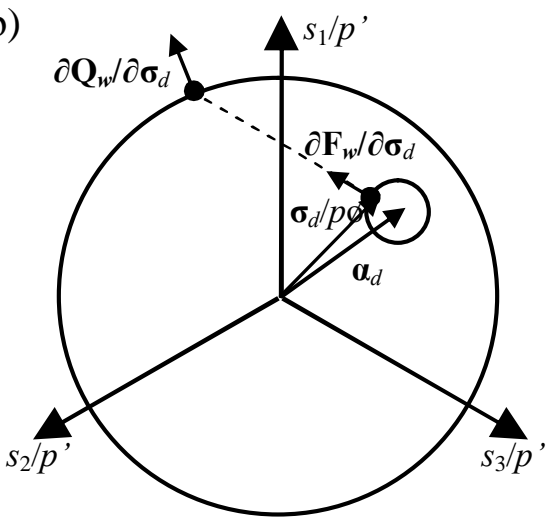

Figure 2: Two possible mapping rules

Rule (a): The image stress point on the bounding surface, $\boldsymbol{\sigma}_{b, d}$, are mapped through a locally modified Lode angle, $\theta^{\alpha}$. The locally modified Lode angle will follow the same direction as the normal to the cone yield surface. The locally modified Lode angle is calculated from the stress tensor $\underline{\underline{s}}^{\alpha}$ given in Equation (20). 
$\boldsymbol{\sigma}_{b, d}=M_{b}\left(\theta^{\alpha}\right) \cdot \sqrt{\frac{2}{3}} \cdot \frac{\partial F_{w}}{\partial \sigma_{d}} \cdot p^{\prime} \quad$ é é é é é é é é é é é é é é é é é é é é é é

$$
\begin{aligned}
& \underline{\underline{s}}^{\alpha}=\underline{\underline{\sigma}}-\underline{\underline{\alpha}} \cdot p^{\prime} \\
& =\left[\begin{array}{ccc}
\sigma_{x}{ }^{\prime}-\alpha_{x} p^{\prime} & \tau_{x y}-\alpha_{x y} p^{\prime} & \tau_{x z}-\alpha_{x z} p^{\prime} \\
\tau_{x y}-\alpha_{x y} p^{\prime} & \sigma_{y}{ }^{\prime}-\alpha_{y} p^{\prime} & \tau_{y z}-\alpha_{y z} p^{\prime} \\
\tau_{x z}-\alpha_{x z} p^{\prime} & \tau_{y z}-\alpha_{y z} p^{\prime} & \sigma_{z}{ }^{\prime}-\alpha_{z} p^{\prime}
\end{array}\right] \quad \text { é é é é é é é é é é é é é é é é é é é } .
\end{aligned}
$$

Rule (b): The image stress point is found by adding a vector to the current stress condition in the direction of the normal to the yield surface according to Equation (21).

$\boldsymbol{\sigma}_{b, d}=\boldsymbol{\sigma}_{d}+\frac{2}{3} \cdot \frac{\partial F_{w}}{\partial \boldsymbol{\sigma}_{d}} \cdot c \cdot p^{\prime} \quad$ é é é é é é é é é é é é é é é é é é é é é é é é é

The condition in Equation (22) must be satisfied, and thus gives the size of $c$.

$F_{b}=\sqrt{\frac{3}{2} \cdot\left\{\boldsymbol{\sigma}_{b, d}\right\}^{T} \cdot \boldsymbol{\sigma}_{b, d}}-M_{b}(\theta) \cdot p^{\prime}=0 \quad$ é é é é é é é é é é é é é é é é é é é é.

For simple triaxial stress paths the mapping rule (a) and (b) will be equal. However in general loading conditions the mapping rule (b) could give more realistic results for the flow direction. Mapping rule (a) gives higher computational efficiency than mapping rule (b).

Differentiation of the yield and potential surfaces are in principle performed as follows:

$$
\frac{\partial(F, Q)}{\partial \boldsymbol{\sigma}}=\frac{\partial \boldsymbol{\sigma}_{d}}{\partial \boldsymbol{\sigma}} \cdot \frac{\partial(F, Q)}{\partial \boldsymbol{\sigma}_{d}}+\frac{\partial p^{\prime}}{\partial \boldsymbol{\sigma}} \cdot \frac{\partial(F, Q)}{\partial p^{\prime}} \quad \text { é é é é é é é é é é é é é é é é é é } \ldots
$$

\section{MODEL SIMULATION}

Model simulation was done using different combinations of parameters as shown in Bujulu and Grimstad (2012), The rule for adding response from several yield criteria and plastic potential functions, known as the Koiter rule (Schanz et al., 1999), was applied. An example of the simulation is given herein, as Figures 3 \& 4, for Mix 1, lime-wastepaper sludge ash (WSA),

\begin{tabular}{|c|c|c|c|c|c|c|c|c|c|c|c|c|c|}
\hline Mix & 3 & $\partial^{*}$ & $\bar{X}_{\mathrm{a}}$ & ü & $\mathrm{a}_{\mathrm{w} 0}$ & $\varepsilon_{\mathrm{w}}$ & $\varepsilon_{\mathrm{aw}}$ & z & $\mathrm{a}_{\mathrm{c} 0}$ & 6 & $\ell$ & $\varepsilon_{\mathrm{ac}}$ & pmô \\
\hline & - & - & $\mathrm{kPa}$ & o & $\mathrm{kPa}$ & - & - & - & $\mathrm{kPa}$ & - & $\mathrm{kPa}$ & - & $\mathrm{kPa}$ \\
\hline 1 & .15 & .0035 & 300 & 41 & 90 & 1500 & 20 & .94 & 330 & .19 & 2800 & 1.2 & 340 \\
\hline 2 & .12 & .01 & 3400 & 44 & 120 & 3200 & 55 & 1.02 & 303 & .14 & 3800 & 48 & 350 \\
\hline 3 & .01 & .019 & 2100 & 37 & 210 & 2000 & 60 & 1.05 & 320 & .18 & 5000 & 200 & 350 \\
\hline 4 & .15 & .005 & 2000 & 42 & 120 & 2500 & 22 & 1.2 & 300 & .17 & 2600 & 5 & 330 \\
\hline
\end{tabular}
(50:50), $100 \mathrm{~kg} / \mathrm{m}^{3}$ for 90 days curing period (Bujulu, 2008).

Table 1: Model parameters (Source: Bujulu and Grimstad, 2012) 
Figure 3 shows typical results from simulation of undrained triaxial shearing for different isotropic consolidation cell pressure, whereas Figure 4 shows typical results from oedometer simulations. The simulation curves are plotted against the respective experimental data for calibration purposes. It can be seen that the model simulations fit well to the laboratory data.
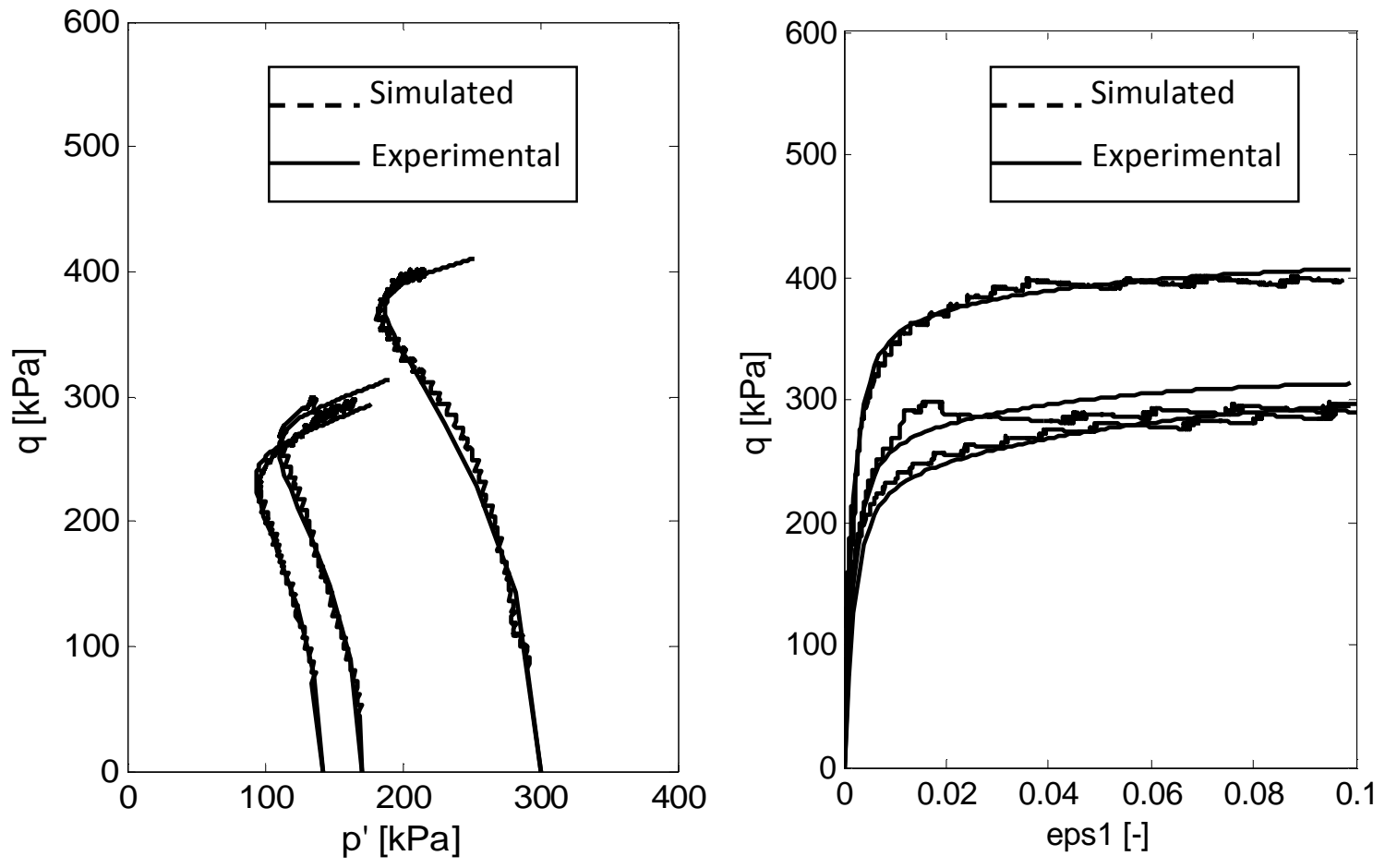

Figure 3. Simulation of triaxial compression - Mix 1
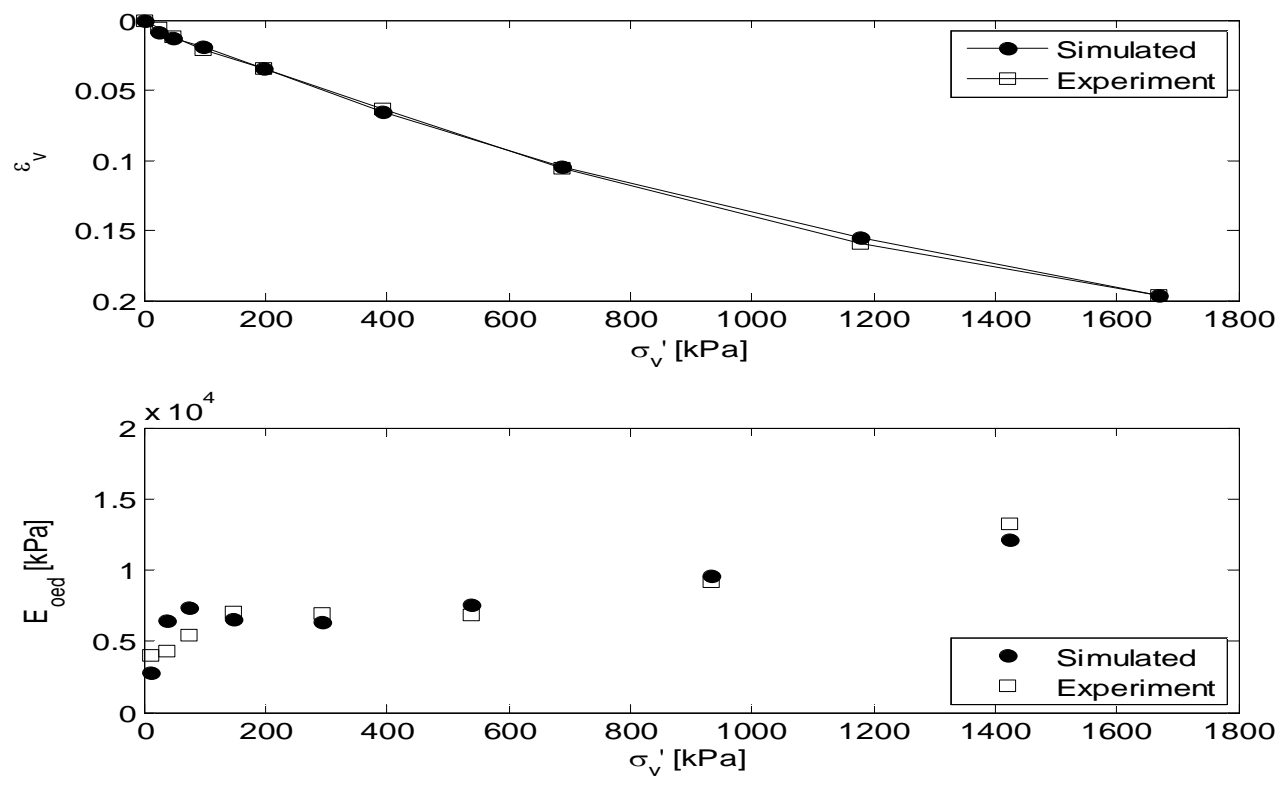

Figure 4: Simulation of oedometer strain and modulus - Mix 1 


\section{CONCLUSION}

A constitutive model for L-(C)-WSA stabilized quick clay which was formulated in the triaxial pô ï q space (Bujulu and Grimstad, 2012) has been extended to cover the 3D free stress space. Simulations for the model were obtained by a single stress point integration algorithm. The model simulations show good agreement with laboratory results. However, an extensive parametric study should be done in order to thoroughly explain the behavior of the model. Extension to include an anisotropic cap-surface is recommended, e.g. using the approach found in Wheeler et al. (2003).

\section{ACKNOWLEDGMENTS}

This research was carried out as a part of the Marie Curie Research Training Network ñAdvanced Modeling of Ground Improvement on Soft Soils (AMGISS)ò (Contract No MRTN-CT2004-512120) supported by the European Community through the program riHuman Resource and Mobilityò The authors want to hereby acknowledge the financial support extended by the AMGISS project and the material support and labour assistance provided in the course of this research by the Norwegian University of Science and Technology (NTNU, Trondheim).

\section{REFERENCES}

Andrianopoulos, K. I., Papadimitriou, A. G and Bouckovalas, G. D., 2005. Bounding Surface Models of Sands: Pitfalls of Mapping Rules for Cyclic Loading, $11^{\text {th }}$ International Conference of IACMAG, Torino, Italy; June 19-24, 1, 241 ï 248.

Brinkgreve, R. B. J., Al-Khoury, R., Bakker, K. J., Bonnier, P. G., Brand, P. J. W., Broere, W., Burd, H. J., Soltys, G., Vermeer, P. A and Waterman, D., 2006. PLAXIS 2D version 8 user manual [online]. Available at www.plaxis.nl. [Accessed on February $22^{\text {nd }}, 2008$ ]

Bujulu, P. M., 2008. Deep-mix Stabilization of Quick Clay: A Potential Area for Utilization of Wastepaper Sludge Ash. PhD Thesis No. 2008:212. Norwegian University of Science and Technology, Trondheim, Norway
Bujulu, P. M and Grimstad, G., 2012. Constitutive Model for Cemented Quick Clay in DeepMix Stabilization. Global Journal of Engineering Research (GJENR), 11, (1): (2012)

Dafalias, Y. F and Manzari, M. T., 2004. Simple Plasticity Sand Model Accounting for Fabric Change Effects, Journal of Engineering Mechanics, 130, (6): 622634.

Karstunen, M., Wiltafsky, C., Krenn, H., Scharinger, F and Schweiger, H. F., 2006. Modelling the behaviour of an embankment on soft clay with different constitutive models. Int. J. Numer. Anal. Meth. Geomech., (in press), Published online in Wiley InterScience. Available at www.interscience.wiley.com DOI: 10.100 2/nag.507 [Accessed on February $25^{\text {th }}$, 2008]

Schanz, T., Veermer, P. A and Bonnier, P. G., 1999. The hardening soil model: Formulation and verification, Beyond 2000 in Computational Geotechnics ï 10 Years of PLAXIS, Balkema, Rotterdam, ISBN 905809040

Søreide, O. K., 2003. Mixed hardening models for frictional soils, Ph.D. thesis 2003:21, NTNU, Trondheim, Norway

Wheeler, S. J., Näätänen, A., Karstunen, M and Lojander, M., 2003. An anisotropic elastoplastic model for natural soft clays. Canadian Geotechnical Journal 40, 403-418. 